Environment Conservation Journal 15(3) 89-93, 2014

ISSN 0972-3099 (Print) 2278-5124 (Online)

Abstracted and Indexed

\title{
Effect of temperature on the occurrence of Desmids in a lentic water body of Bhopal district, M.P. with reference to seasonal variation in the physico- chemical parameters
}

\author{
Bhawana Agrawal $\bowtie$ and Pramod Patil
}

Received: 12.12.2013

Revised: 06.05.2014

Accepted:14.08.2014

\begin{abstract}
The aim of the study was to assess the effect of temperature on the occurrence of desmids on a lentic waterbody viz. Jawahar Bal Udhyan Pond situated in northern direction of the Bhopal district with reference to its seasonal variation in physico-chemical parameters. Water temperature of the lentic water body varied between $16.2^{\circ} \mathrm{C}$ to $31.9^{\circ} \mathrm{C}$ in winter and summer season respectively. During the present study period a total of 18 desmid taxa of 6 genera were encountered in which Cosmarium dominated in terms of species diversity. Desmids occurred maximum in winter season i.e., from December to February and minimum in post monsoon season i.e., from October and November. Different species of Closterium, Euastrum, Staurastrum, Pleurotaenium, and Sphaerozosma are considered as pollution tolerant species and the presence of all these species and result of physico-chemical parameters indicates the meso-eutrophic condition of the waterbody.
\end{abstract}

Keywords: Bhopal district, desmid species, lentic systems, meso-eutrophic, physico- chemical parameters, water temperature

\section{Introduction}

The demand on lakes, reservoirs, ponds and rivers is increasing for the drinking water and many other uses, but due to speedy industrialization the pollution is rising up (Singh and Mathur, 2005). There is an interesting side of lakes, reservoirs and ponds is the characteristic change due to seasonal variations which results in change in water volume, salt concentration, dissolved substances and organic matters and as a result affects the plant life. Therefore the annual monitoring of water bodies by checking out the algal diversity and physicochemical parameters provides a scientific way to manage such types of water bodies. Phytoplanktons which include green algae, blue green algae, diatoms, desmids, euglenoids etc. are important among the aquatic flora. They are ecologically significant as they form the basic link in the food chain of all aquatic animals (Misra et al., 2001). When in large number they make water greenish. The algae have a major role in oxygen enrichment of water, binding and removal of certain toxic

\section{Author's Address}

${ }^{1}$ Department of Botany, Govt. M.L.B. Girls P.G.College

Bhopal, M.P.

E-mail:bhawana.agrawal9@gmail.com

Copyright by ASEA

All rights of reproduction in any form reserved substances. The algal and specially the desmid contributions are very crucial for water quality improvement. The aquatic environment supports hydrophytic vegetation with abundant growth of algae. Considerable amount of work has been done about systematic survey, distribution and periodicity of algae in different habitats of Bhopal district but information on desmids is lacking. Therefore in the present study focus has been made on desmids and effect of temperature on their occurrence in different seasons.

The study area selected was Jawahar Bal Udhyan Pond of Bhopal (fig. 1), the state capital of Madhya Pradesh. Bhopal is located in the central region of India and in north-western part of the state. Jawahar Bal Udyan Pond, a man made reservoir, (longitude $77^{\circ} 35^{\prime} \mathrm{E}$; latitude $23^{\circ} 25^{\prime} \mathrm{N}, 225$ meter above mean sea level) is situated on the main road no.2, connecting South T.T. Nagar with Habibganj railway station, Bhopal. It is located on the down side of Char-Imli hills and is enveloped on remaining three sides by link roads leading to the residential area of Char- Imli. 


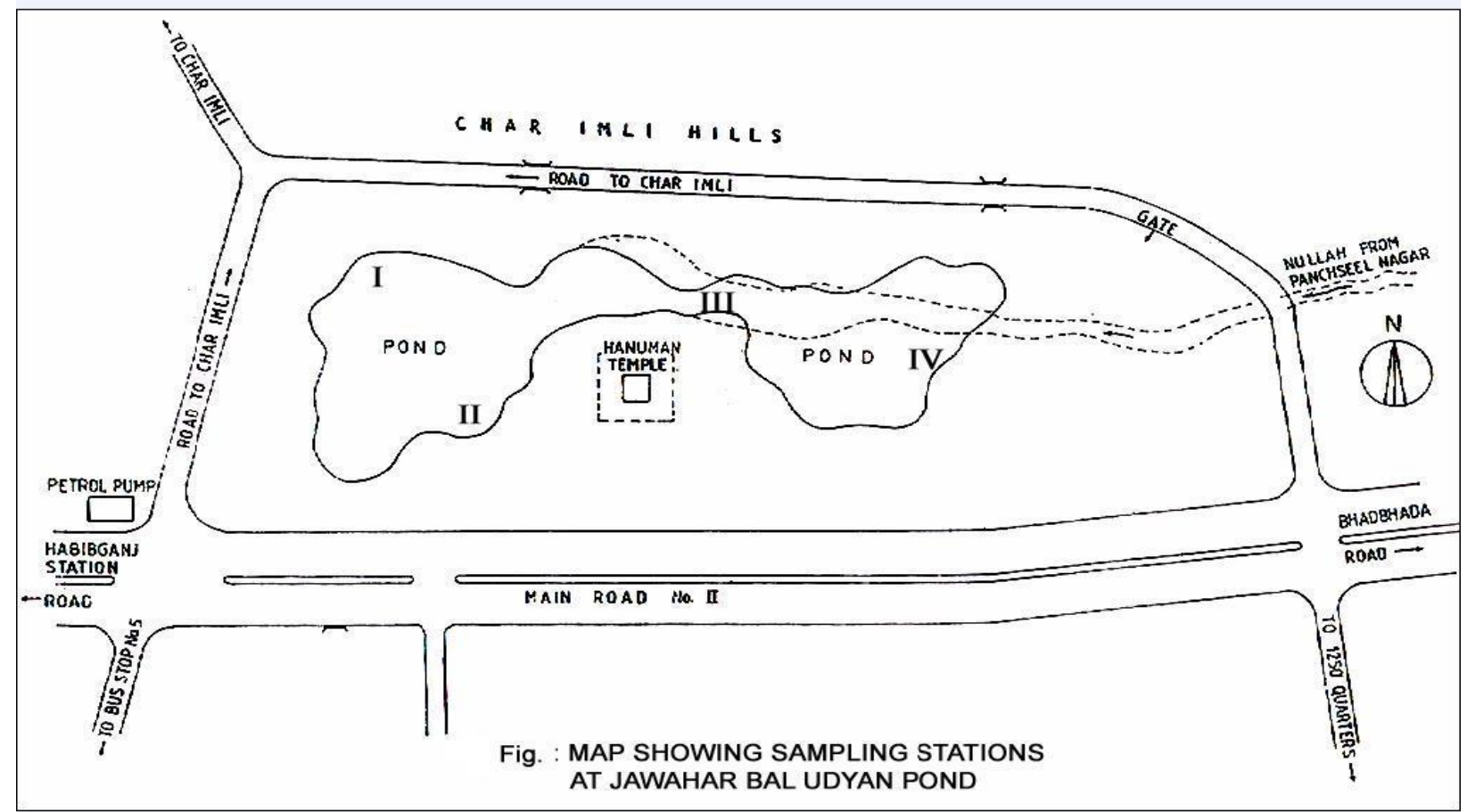

Figure 1: Map showing different sampling stations of study area

\section{Material and Methods}

The water samples were collected during December 2006 to November 2007 from four different sampling stations of Jawahar Bal Udhyan Pond in four different seasons i.e.; winter, summer, monsoon and post monsoon season. While selecting the sampling stations, care was taken for collecting water and algal samples in such a manner that the collected samples represented pond in all respects. In each season three samplings (monthly) were made. Parameters like atmospheric temperature, water temperature, transparency were recorded at the sampling site. The samples were analyzed in the laboratory on the same day of collection for important physico-chemical parameters like $\mathrm{pH}$, DO, alkalinity, chloride, calcium, phosphate, total hardness, nitrite and nitrate. All the physicochemical parameters were determined adopting methods given by Adoni (1985), NEERI (1986), APHA (1998). Algal samples were collected from surface upto a depth of half a meter. The samples were brought in laboratory in $200 \mathrm{ml}$ glass bottles. All algal samples were examined under the light microscope and the samples were preserved in $4 \%$ formalin for future study. Identification of the forms has been made with the help of work done earlier by Croasdale and Gronblad (1964), Hinode
(1966), Bicudo (1969), Agarkar (1971), Agarkar and Agarkar (1972, 1979).

\section{Results and Discussion}

The data of physical and chemical analysis is presented in Table 1 . The water temperature ranged between $16.2^{\circ} \mathrm{C}$ to $31.9^{\circ} \mathrm{C}$. The maximum temperature was recorded in the month of May and minimum in the month of January. The $\mathrm{pH}$ varied between 7.7 and 8.7. Minimum value was found in the monsoon season and maximum in summer season. $\mathrm{pH}$ was towards alkaline side throughout the study period. Alkaline nature of water could be attributed to enhanced photosynthetic activity. The Secchi transparency varied from $14.6 \mathrm{~cm}$ to $65 \mathrm{~cm}$. Maximum Secchi value was recorded during summer months and minimum was recorded in October. The low transparency value can be attributed to the incoming silt from the catchment area during monsoon and post monsoon season. Dissolved oxygen (DO) value $12.4 \mathrm{mg} / \mathrm{l}$ was maximum in the month of April and minimum 7 $\mathrm{mg} / \mathrm{l}$ in the month of November. DO did not showed any definite pattern but its higher concentration during summer season shows its correlation with water temperature.Total hardness 
varied between $200 \mathrm{mg} / \mathrm{l}$ to $260 \mathrm{mg} / \mathrm{l}$. Maximum hardness was observed in the month of January and minimum in the month of June. High value of total hardness shows hard water character and strongly correlated with calcium. Calcium is an important nutrient for aquatic organisms. Calcium hardness ranged from $56.1 \mathrm{mg} / \mathrm{l}$ to $80.5 \mathrm{mg} / \mathrm{l}$. Maximum value of calcium hardness was observed in the month of June and minimum in the month of August. This observation indicates the water body is calcium rich, which is due to dumping of solid waste and its decomposition in the segments. The chloride content showed the highest value of 51.2 $\mathrm{mg} / \mathrm{l}$ in the month of June and lowest value of 29.3 $\mathrm{mg} / \mathrm{l}$ in the month of September. High concentration of chloride in the pond reflects the presence of high amount of organic pollutant (Jha and Verma, 2000). Sharma et. al. (1978) pointed out that chloride content also increase with the degree of eutrophication. Maximum alkalinity value recorded was $144.2 \mathrm{mg} / \mathrm{l}$ in the month of May and minimum value of $105 \mathrm{mg} / \mathrm{l}$ in the month of January. Phosphate content in Jawahar Bal Udhyan Pond ranged from $0.19 \mathrm{mg} / \mathrm{l}$ in the month of December to $0.08 \mathrm{mg} / \mathrm{ln}$ the month of May and June. The increase in phosphate may be due to use of detergents and soaps during bathing and washing. Nitrite content ranged from $0.007 \mathrm{mg} / \mathrm{l}$ to $0.10 \mathrm{mg} / \mathrm{l}$. Maximum value was observed in the month of April. Nitrate value $1.0 \mathrm{mg} / \mathrm{l}$ was maximum in the

Table 1: Seasonal Variation in various physico-chemical parameters of pond water

\begin{tabular}{|l|l|l|l|l|l|l|l|l|}
\hline Seasons & \multicolumn{2}{l|}{$\begin{array}{l}\text { Winter } \\
\text { (Dec.-Feb. }\end{array}$} & \multicolumn{2}{l|}{$\begin{array}{l}\text { Summer } \\
\text { (Mar.-May) }\end{array}$} & \multicolumn{2}{l|}{$\begin{array}{l}\text { Monsoon } \\
(\text { Jun.-Sept.) }\end{array}$} & \multicolumn{2}{l|}{$\begin{array}{l}\text { P. monsoon } \\
\text { (Oct.-Nov. }\end{array}$} \\
\hline Parameters $\downarrow$ & Min. & Max. & Min. & Max. & Min. & Max. & Min. & Max. \\
\hline Air temp. $\left({ }^{\circ} \mathrm{C}\right)$ & 11.3 & 30 & 17.7 & 40.8 & 22.7 & 37.6 & 14.9 & 33.3 \\
\hline Water temp. $\left({ }^{\circ} \mathrm{C}\right)$ & 16.2 & 20.1 & 23.4 & 31.9 & 22.6 & 30.5 & 22.5 & 23.0 \\
\hline Transparency $(\mathrm{cm})$ & 20 & 52 & 46 & 65 & 14.8 & 31.8 & 14.6 & 20.7 \\
\hline $\mathrm{pH}$ & 7.9 & 8.6 & 8.3 & 8.7 & 7.7 & 8.5 & 7.9 & 8.2 \\
\hline DO $(\mathrm{mg} / \mathrm{l})$ & 7.6 & 10.9 & 9.9 & 12.4 & 8.3 & 10.4 & 7.0 & 9.3 \\
\hline Total hardness $(\mathrm{mg} / \mathrm{l})$ & 201 & 260 & 235 & 260 & 200 & 240 & 210 & 247 \\
\hline Calcium $(\mathrm{mg} / \mathrm{l})$ & 65.7 & 78.0 & 65 & 70 & 56.1 & 80.5 & 65 & 68.5 \\
\hline Chloride $(\mathrm{mg} / \mathrm{l})$ & 35.2 & 38.5 & 38.5 & 49.7 & 29.3 & 51.2 & 29.5 & 29.5 \\
\hline Total alkalinity $(\mathrm{mg} / \mathrm{l})$ & 105 & 121.5 & 121 & 144.2 & 111.7 & 121.7 & 110 & 127.5 \\
\hline Phosphate $(\mathrm{mg} / \mathrm{l})$ & 0.10 & 0.19 & 0.08 & 0.11 & 0.08 & 0.10 & 0.13 & 0.16 \\
\hline Nitrite $(\mathrm{mg} / \mathrm{l})$ & .008 & 0.020 & 0.007 & 0.08 & 0.009 & 0.10 & 0.008 & 0.011 \\
\hline Nitrate $(\mathrm{mg} / \mathrm{l})$ & 0.30 & 1.0 & 0.03 & 0.06 & 0.04 & 0.81 & 0.65 & 0.99 \\
\hline
\end{tabular}

month of January and minimum $0.03 \mathrm{mg} / \mathrm{l}$ in the month of April. The high concentration of nitrate may be due to release of nitrate during microbial decomposition of dead organic matter (Goldman and Horne, 1994).The results of biological analysis are expressed in Table 2. A total of 18 taxa belonging to 6 genera were observed. The dominant genus of desmid was Cosmarium. A total of 6 taxa of Cosmarium dominated over others. Cosmarium was followed by Closterium, which was followed by Euastrum and Staurastrum both having same number of taxa i.e. 6 .
These were followed by Pleurotaenium and Sphaerozosma having one taxon each. The presence of Closterium kuetzingii, Pleurotaenium ehrenbergii, Sphaerozosma granulatum recorded as tolerant species for slightly polluted water (Coesel 1983). month of January and minimum $0.03 \mathrm{mg} / \mathrm{l}$ in the month of April. The high concentration of nitrate may be due to release of nitrate during microbial decomposition of dead organic matter (Goldman and Horne, 1994). The results of biological analysis are expressed in Table 2. 
Agrawal and Patil

Table 2: Occurrence of desmids in different seasons in pond water

\begin{tabular}{|l|l|l|l|l|}
\hline $\begin{array}{l}\text { Seasons } \rightarrow \\
\text { Desmids } \downarrow\end{array}$ & $\begin{array}{l}\text { Winter } \\
\text { Dec.-Feb. }\end{array}$ & $\begin{array}{l}\text { Summer } \\
\text { Mar.-May }\end{array}$ & $\begin{array}{l}\text { Monsoon } \\
\text { Jun.-Sept. }\end{array}$ & $\begin{array}{l}\text { P.monsoon } \\
\text { Oct.-Nov. }\end{array}$ \\
\hline Closterium dianae & $\mathrm{c}$ & $\mathrm{r}$ & - & - \\
\hline C. dianae var. minus & $\mathrm{r}$ & - & - & - \\
\hline C. kuetzingii & $\mathrm{r}$ & - & - & - \\
\hline C. venus & $\mathrm{r}$ & - & - & $\mathrm{c}$ \\
\hline Pleurotaenium ehrenbergii & $\mathrm{c}$ & - & - & $\mathrm{r}$ \\
\hline Euastrum binale & $\mathrm{vc}$ & - & - & - \\
\hline E. spinulosum & $\mathrm{a}$ & $\mathrm{c}$ & $\mathrm{r}$ & - \\
\hline E. substellatum forma & $\mathrm{r}$ & - & - & - \\
\hline Cosmarium beatum & $\mathrm{c}$ & $\mathrm{r}$ & $\mathrm{r}$ & - \\
\hline C. bengalense & $\mathrm{c}$ & - & $\mathrm{r}$ & - \\
\hline C. blyttii & $\mathrm{c}$ & $\mathrm{c}$ & $\mathrm{r}$ & $\mathrm{r}$ \\
\hline C. humile & $\mathrm{c}$ & $\mathrm{c}$ & $\mathrm{r}$ & - \\
\hline C. paradoxum & $\mathrm{r}$ & - & $\mathrm{r}$ & - \\
\hline C. subspeciosum & $\mathrm{c}$ & $\mathrm{r}$ & $\mathrm{r}$ & $\mathrm{r}$ \\
\hline Staurastrum hexacerum & $\mathrm{c}$ & - & $\mathrm{r}$ & - \\
\hline S. punctulatum & $\mathrm{c}$ & $\mathrm{c}$ & $\mathrm{r}$ & $\mathrm{c}$ \\
\hline S.tetracerum & $\mathrm{vc}$ & $\mathrm{c}$ & $\mathrm{r}$ & - \\
\hline Sphaerozosma granulatum & $\mathrm{c}$ & $\mathrm{r}$ & $\mathrm{r}$ & $\mathrm{c}$ \\
\hline
\end{tabular}

(a) = abundant; $(\mathrm{vc})=$ very common; $(\mathrm{c})=$ common; $=(\mathrm{r})=$ rare; $(-)=$ absent

A total of 18 taxa belonging to 6 genera were observed. The dominant genus of desmid was Cosmarium. A total of 6 taxa of Cosmarium dominated over others. Cosmarium was followed by Closterium, which was followed by Euastrum and Staurastrum both having same number of taxa i.e. 6. These were followed by Pleurotaenium and Sphaerozosma having one taxon each. The presence of Closterium kuetzingii, Pleurotaenium ehrenbergii, Sphaerozosma granulatum recorded as tolerant species for slightly polluted water (Coesel 1983). Therefore, these species could be called as the indicator species and are used to describe mesoeutrophic status of Jawahar Bal Udhyan Pond. The maximum number of species was observed in winter season and early summer when temperature was quite low. Govind (1963), Kant and Kachroo (1977), Gonzalves and Joshi (1946) also recorded desmids in large number hen water experienced low temperature. This does not confirm to the observation of Rao (1955) and Pearsall (1932) who noted an abundance of desmids in summer and Woodhead and Tweed (1947) who found a desmids maxima in spring. According to Reynolds (1973) desmids found throughout the year but the highest population was recorded in autumn and winter. Thus, it may be concluded that the density of desmid is dependent on different abiotic factors either directly or indirectly. With the help of the observations it can be stated that the pond under investigation is meso-eutrophic in nature and proceeding towards eutrophic condition. It is advised that necessary steps should be taken to check the eutrophication.

\section{Acknowledgement}

The author is thankful to Ms. Alankrita Agrawal and Mr. Mukund Agrawal for their continous support and encouragement throughout the work. 


\section{References}

Adoni, A.D., G. Joshi, K. Gosh, S.K. Chourasia, A.K. Vaishya, M. Yadav and H.G.Verma 1985. Workbook on Limnology, Pratibha Publishers, Sagar, 1-216.

Agarkar, D.S. 1971. Contribution to the Desmids of Gwalior, Madhya Pradesh, India II.Phykos, 10: 54-69.

Agarkar, D.S. and Agarkar, M.S. 1972. Contribution to the Desmids of Madhya Pradesh, India (Desmids from Vindhyan region).

Agarkar, D.S. and Agarkar, M.S. 1979. Desmids from Bandhavgarh, Madhya Pradesh, India.Hydrobiologia, 65: 213 - 223.

APHA, American Public Health Association 1998. Standard method for the examination of water and wastewater, $20^{\text {th }}$ Edition, American Public Health Association Washington D.C.

Bicudo, C. E. M. 1969. Contribution to the knowledge of the Desmids of the State of Sao - Paulo (Brazil). Nova Hedwigia, 16 : 433-549.

Coesel, P.F.M. 1983. Desmids of the Netherlands, 2.Family Closteriaceae. Wet. Meded. K.N.N.V. (K. Ned. Nature.rhist. ver.).157: $1-49$.

Croasdale, H. and Gronblad, R. 1964. Desmids of Labrador I. Desmids of the South Eastern Coastal Area Trans. Am. Micro. Soc. 84 : $301-335$.

Goldman, C.R. and Horne, A.J. 1983. Limnology, McGraw Hill, International Book Company, New Delhi.

Gonzalves, E.A. and Joshi, D.B. 1946. Fresh water algae near Bombay.J. Bombay Nat. Hist. Soc., 46 (1) : 154 - 176.

Govind, B.V. 1963. Preliminary studies on plankton of the Tungabhadra Reservoir. Indian J. Fish., 10 : 148 - 158.
Hinode, T. 1966. Desmids from the northern district of Tokushima Prefecture. J. Jap. Bot., 41 (7) : $214-222$.

Jha, A.N. and Verma, P.K. 2000. Physico-chemical properties of drinking water in town area of Godda district under SantalPargana (Bihar), India. Poll. Res. 19(2): 245-247.

Kant, S. and Kachroo, P. 1977. Limnological studies in Kashmir lakes I. Hydrological features, composition and periodicity of phytoplankton in the Dal and Nagin lakes, Phykos, 15(1 - 2) : 77 - 97.

Misra, S. M., Pani, S., Bajpai, A. and Bajpai, A.K. 2001. Assessment of trophic status by using Nygaard index with reference to Bhoj wetland.Poll. Res. 20(2):147-153.

NEERI. 1986. Course manual. Water and wastewater analysis, NEERI, Nagpur, pp.134.

Pearsall, W.H. 1932. Phytoplankton in the English Lake II. The composition of the phytoplankton in relation to dissolved substance. J. Ecol., 20: 241 - 262.

Rao, C.B. 1955. On the distribution of algae in a group of six small ponds. II. Algal periodicity. J. Ecol., 43: 291 - 308.

Reynolds, C.S. 1973. Phytoplankton periodicity of some North Shropshire Meres. J. Br. Phycol., 8: 301 - 320.

Sharma, K.P., Goel, P.K. and Gopal, B. 1978. Limnological studies of polluted freshwater. Int. J. Ecol. Environ., 4: 89-105.

Singh, R.P. and Mathur, P. 2005. Investigation of variations in physic-chemical characteristics of a fresh water reservoir of Ajmer city, Rajasthan. Indian Journal of Environmental Science, 9:57-61.

Woodhead, H. and Tweed, R.D. 1947. Some algal flora of high altitudes in Snowdonia. Northw. Nat. March and June, $34-$ 42. 